\title{
AFRICANOS E CRIOULOS NO CAMPESINATO NEGRO DO MARANHÃO OITOCENTISTA $^{1,2}$
}

\section{AFRICAN AND CREOLE THE PEASANTRY MARANHÃO BLACK NINETEENTH CENTURY}

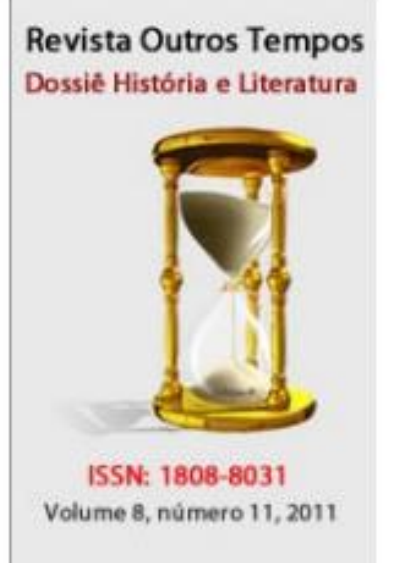

\author{
FLÁVIO GOMES \\ Doutor pela UNICAMP \\ Professor da Universidade Federal do Rio de Janeiro \\ escravo@prolink.com.br
}

Resumo: O presente artigo trata de questões relacionadas ao campesinato negro intuído no Brasil através de uma análise da Província do Maranhão durante o século XIX. Esse foi um período de proliferação de quilombos e da economia camponesa, favorecendo a resistência escrava protagonizadas por crioulos e africanos.

Palavras chaves: Quilombos. Maranhão. Crioulos. Africanos.

Abstract: This paper is on questions about maroons in Maranhão Province during $19^{\text {th }}$ Century. There was a lot maroons in this period within a rural economy. It is collaborated with a Slave resistance that African and Creoles people participated.

Keywords: Maroons. Maranhão. Africans. Creoles.

\footnotetext{
${ }^{1}$ Artigo submetido à avaliação em 28/02/2011 e aprovado para publicação em 28/05/2011.

${ }^{2}$ Uma primeira versão de parte deste texto foi publicada com o título de "Uma lança em África": notas sobre fontes e narrativas numa repressão anti-mocambo no Maranhão Oitocentista", in: GOMES, Flávio dos Santos. Experiências atlânticas: Ensaios e pesquisas sobre a escravidão e o pós-emancipação no Brasil. Passo Fundo-RS: UPF Editora -- Universidade de Passo Fundo-RS, 2003.
} 
Setores camponeses se formaram a partir das senzalas, dos mocambos e de roceiros livres. Para várias regiões, há evidências de como escravos e quilombolas faziam circular produtos de sua economia agrária. E mesmo articulações econômicas a partir das quais essa produção camponesa alcançava tabernas, feiras e vilas em áreas rurais e semi-urbanas (GOMES, 2007, p. 147-170). De um modo geral, as fontes históricas a respeito são raras, quando não indiretas. Nas senzalas tudo era clandestino e nos quilombos os registros aparecem em fontes produzidas pela repressão.

Para o Maranhão - nas áreas do Gurupi-Turiaçu - conhecemos detalhes de um campesinato que articulava mocambos e senzalas, dando origem às comunidades negras rurais e o acesso a terra ainda na escravidão. Como funcionava? Alguns produtos que complementavam a economia de quilombos - servindo como moeda de troca - vinham das roças e da economia própria daqueles que permaneciam nas senzalas, estabelecendo alianças, ampliando bases econômicas, autonomia e proteção. Embora permeadas por tensões, surgiam redes de trocas junto às fazendas, povoados, feiras e vilas. Na província maranhense se reclamava desse circuito mercantil, pois nas lavouras a "desgraça é maior" uma vez que "os escravos furtam o algodão dos senhores e vão vender ou aos mascates ou aos fazendeiros vizinhos, geralmente os fazendeiros compram aos escravos dos vizinhos o algodão furtado fingindo supor que provem das pequenas roças dos vendedores ou de compra por estes feita". Além disso, "é quase geral o acoitarem escravos fugidos uns dos outros; desfrutando-lhes o serviço que querem prestar pelo alimento e promessa de compra ou proteção". ${ }^{3}$ Tal cenário, em vez de atípico, revela as margens estreitas que aproximavam as comunidades de senzalas e as comunidades de fugitivos. Em Viana, junto à fazenda Santa Bárbara, dizia-se haver um pequeno quilombo com escravos, que descobertos ainda nas matas da fazenda, estariam fazendo farinha para seguirem em direção a um dos grandes quilombos localizados no rio Turiaçu. Em 1865 foi noticiado que o líder do quilombo chamado São Benedito do Céu tinha um plano de invadir a fazenda Santa Bárbara à noite para cometer assassinatos, insatisfeito que estava com as atitudes senhoriais para com aqueles que permaneciam nas senzalas. Desde muito tempo - segundo depoimentos quilombolas do São Benedito do Céu obtinham sal e ferramentas com escravos e lavradores locais. Sobre a invasão, os quilombolas "desistiram por que um clube com escravos da fazenda com que entretêm relações decidiu-se o contrário, com o fim de não comprometer os escravos da fazenda". 4

\footnotetext{
${ }^{3}$ Arquivo Nacional do Rio de Janeiro (doravante ANRJ), IJ1 218, Ofícios (1842-1844), Ofício de 07/04/1843.

${ }^{4}$ Arquivo Público do Estado do Maranhão (doravante APEMA), Série: Juízes de Paz/Chefe de Polícia (1845-1887), Correspondência de 09/03/1865.
} 
Habitantes dos quilombos - em determinados períodos - podiam fazer grandes deslocamentos, para efetuarem trocas mercantis ou reencontrar seus parentes que continuavam nas fazendas. No Maranhão se dizia que "reconcentram-se ao quilombo bem providos de armamentos e munição, e dos escravos que podem recrutar aos lavradores, que lhes não dão apoio". Assim, os escravos de lavradores que não apoiassem - através de comércio, proteção ou mesmo negligência ou pouco interesse em capturá-los - seriam alvos da "sedução" no sentido de ir para o quilombo. Com ou sem a conveniência e omissão de determinados fazendeiros, alguns quilombolas, além de realizarem trocas mercantis, pernoitavam nas senzalas ou acampavam nas próprias terras de grandes fazendas. Com maior destaque, assim foi definida a fazenda Santa Bárbara: "pode, sem medo de errar, qualificar-se de outro quilombo pela indisciplina, falta de repressão, sua situação em caminho dos negros fugidos com quem os escravos estão em contato diariamente no tempo da seca. É este o conceito que goza essa fazenda há muitos anos". Algumas fazendas podiam ser classificadas como um verdadeiro quilombo não só porque os seus escravos mantinham contatos com os quilombolas, mas também devido à insubordinação cotidiana e pressão aos senhores, por exemplo, por mais autonomia, ditando o tempo do trabalho nas lavouras, cultivando roças, comercializando produtos e realizando batuques e festas religiosas com maior freqüência etc. ${ }^{5}$

A economia camponesa dos mocambos do Gurupi-Turiaçu - ao considerar os relatos das expedições enviadas para destruí-los ao longo do século XIX - era vigorosa. Em 1853 sobre as suas localizações: "tem bonitas matas, terra fresca todo de massapés arenoso, misturada de massapés barro, próprio para a cultura de cana e arroz, e abundante de caça". E também: "é abundante de peixes e nas margens povoadas de caça e aves". Na ocasião, anotou-se nestes mocambos: "63 casas espalhadas em uma área de 200 braços quadrados, que se tornava impossível de cerco, existe nestes lugares muita mandioca, batata, cará, macaxeira, em fim muita abundância de mantimento em diferentes roças". ${ }^{6}$ Em 1864 assim se referia à economia mercantil quilombola: "comerciam com os pretos fugidos todos os mascates e negociantes colocados nos centros, visto que tendo eles de comprar, e vender gêneros aos escravos de muitas fazendas, que estão em contato com os negros fugidos estes com aqueles se associam nas suas digressões noturnas como oportuna ocasião para tais empresas sem risco de serem conhecidos; assim não lhes é possível evitar qualquer gênero de comércio com eles". 7

\footnotetext{
${ }^{5}$ ANRJ, IJ1 754, Idem, Ofícios (1863), Ofício de 04/11/1863

${ }^{6}$ APEMA, Fundo: Secretaria do Governo, Grupo: Diferentes Particulares, Série: Correspondência, Ofício de $10 / 10 / 1853$

${ }^{7}$ APEMA, Série: Chefes de Polícia/Presidentes, Caixa. nº 18, Ano: 1864, Ofício de 08/08/1864
} 
Talvez pensando neste cenário rural que, de forma original, o positivista Francisco Antônio Brandão Jr. em 1865, ao escrever a obra A Escravatura no Brasil precedida d'um Artigo Sobre Agricultura e Colonização no Maranhão, sugeriu a transformação de quilombolas em colonos. No seu projeto de colonização-emancipação propunha: 1) legislação taxando "ordenado" aos escravos; 2) fim da compra e venda de cativos; 3) introdução de máquinas e tecnologia com a racionalização do trabalho agrícola; 4) fim do castigo físico aos escravos; e 5) legislação estipulando uma taxação para as alforrias proporcional à faixa etária. Concluía afirmando: "em pouco tempo estariam todos os escravos libertos, tendo ainda os estabelecimentos dos fazendeiros para continuarem nos trabalhos da lavoura, para os quais seriam contratados como colonos". Defendia a ideia de uma gradual colonização com a população ex-escrava, incluindo os quilombolas. Para Brandão Jr., os quilombos do Maranhão não se desenvolviam mais devido à condição de "foragidos" de seus habitantes. Ainda assim tinham plantações de milho, arroz, mandiocas, e muitos chegavam a comercializar algodão com alguns fazendeiros em troca de ferramentas e armas. Para o positivista, o "costume" de alguns fazendeiros "venderem fazendas e outros gêneros aos foragidos, estende-se também aqueles que vivem nas fazendas dos seus senhores; e esse mau costume induz os escravos a roubarem aos seus senhores, para trocarem por cachaça, fazendas, etc., em casa destes vendilhões, sedutores de escravos". Como contraponto propunha: "não seria mais justo que o governo tratasse de empregar esses homens como colonos, livrando-os por este meio, de um castigo bárbaro, que só serve de excitar os brancos contra esses infelizes, e estes constantemente a ocultarem-se nas matas". Ele mesmo admitia que alguns mocambos, pelos seus muitos anos de existência, possuíam uma população de terceira e até quarta geração: "E aqui perguntamos, a quem entregam os escravos descendentes de outros que fugiram há quinze ou vinte anos. - sem dúvida que ao primeiro senhor que com os seus velhos documentos de possessão provar que há trinta ou quarenta anos fugiu-lhe uma escrava de nome Joana, e que segundo a legenda do prisioneiro, deve ser, sem dúvida, a mãe ou avó do sobredito cujo!...". O argumento principal de Brandão Jr. era em torno do controle sobre o trabalho e a economia quilombola. (BRANDÃO JUNIOR, 1865$, p. $77,78,86)$

Certamente fragmentos de experiências mais extensivas que devem ter surgido em várias partes e se desdobrado na pós-emancipação. A propósito, no Maranhão - atual estado da federação que ainda mantem preponderantemente a maioria da sua população em áreas rurais existem centenas de comunidades negras rurais e pioneiras entidades de luta pela terra destas populações. (GOMES, 2005, p. 129-324) 


\section{Invadindo os mocambos do Turiaçu}

Os quilombos nas regiões em torno dos rios Turiaçu e principalmente Gurupi eram muito antigos. Nos primeiros anos do século XVIII para lá tinha sido enviado Fernão Carrilho famoso em combater fugitivos, pois tinha participado nos ataques aos mocambos baianos em 1668 e mesmo comandando expedições contra Palmares na década seguinte. Para os anos de 1731, 1739, 1753, 1774 e 1793, a rica documentação colonial do Arquivo Público do Pará informa sobre reclamações e o envio de expedições contra os quilombos do Turiaçu e Gurupi.

Tratava-se de uma área de divisa, situada nos limites entre o Pará e o Maranhão. Ainda em meados do século XVIII, esses limites eram ligados em termos de administração colonial pelo Estado do Maranhão e Grão-Pará, depois foram divididos em duas Capitanias. Com o século XIX tornaram-se respectivamente províncias do Maranhão e Grão-Pará. Até 1852, a região do Turiaçu pertencia ao Pará. Após muitos conflitos passou para a jurisdição do Maranhão. Os limites, antes o rio Turiaçu, passariam a ser o rio Gurupi. Uma margem pertencia ao Pará e a outra ao Maranhão. Quilombolas, grupos indígenas e depois colonos e camponeses fizeram ali suas próprias fronteiras. Tais fronteiras foram marcadas por inúmeras experiências de lutas, alianças e conflitos. Ao longo do século XIX, principalmente na segunda metade, houve intensa mobilização militar para combater os quilombos desta região. Nos anos de 1853 e 1858 e também entre 1863 e 1868, numerosas tropas adentraram essa floresta, invadiram e destruíram mais de 15 mocambos e capturaram quase uma centena de mocambeiros. Encontrariam comunidades camponesas vigorosas e estruturadas - algumas com mais de 600 habitantes - e toda uma rede de comércio, articulando produção e comercialização de farinha e extração de ouro.

Os grandes mocambos de São Benedito do Céu e São Vicente do Céu seriam invadidos pela primeira vez. Verificou-se que essa região tinha importância econômica, posto guardar mananciais auríferos, além de boas terras para o cultivo. Associada à expulsão dos indígenas e à destruição dos quilombos, políticas provinciais maranhenses foram montadas para colonizar a região. Colônias militares seriam instaladas. Empresas de mineração, com capitais estrangeiros e a intermediação do Barão de Mauá ali se fizeram presentes. Como mão de obra foram trazidos colonos portugueses e chineses. Passados alguns anos - mais propriamente no final dos anos 60 - todas as estratégias de ocupação econômica da região do Gurupi conheceriam fracassos. Isso porque a colônia militar ficou deficitária, com maquinário e tecnologias para a mineração afundadas nos igarapés. Além disso, os trabalhadores portugueses e chineses escafederam-se e muitos débitos com os empréstimos bancários internacionais. A região, na verdade, já estava 
bem ocupada em termos geográficos e sócio econômicos com as inúmeras comunidades negras tanto quilombos como camponeses livres e libertos - e grupos indígenas.

As políticas imperiais de imigração e colonização estavam associadas não somente à substituição de mão de obra ou ocupação de fronteiras econômicas abertas. No Gurupi, o sentido era reocupar uma área - desmanchando cenários e eliminando protagonistas - com tradições de lutas e sob o controle de índios e negros. Nos anos 70 e 80, as tentativas de destruição dos mocambos naquela região continuariam. Os grandes mocambos de São Sebastião (1876-1877) e do Limoeiro (1878-1879) foram atacados. Outros projetos de colonização surgiriam, principalmente em 1878, quando retirantes cearenses - fugindo das secas no Nordeste - foram enviados para a região. A política provincial do Maranhão tentava novamente ocupar a região e estabelecer uma colônia - denominada Prado - no mesmo local onde existiu o quilombo do Limoeiro, aproveitando-se mesmo da estrutura de casas e produção econômica, assim como as redes comerciais existentes. Mais uma vez houve fracassos nessas tentativas. (GOMES, 2003)

Nosso objetivo aqui não é recontar a história da tradição camponesa desses quilombos maranhenses, mas sim explorar uma fonte inédita. Vamos tratar da narrativa que aparece no relatório escrito pelo major Honorato Cândido Ferreira Caldas e enviado para o presidente da província, a propósito de uma expedição contra os quilombolas. Pretendemos igualmente “invadir" um quilombo numa perspectiva etnográfica, tentando desvendar sinais, significados e símbolos de uma cultura de camponeses negros, quilombolas, no Maranhão oitocentista.

Em fins de 1876 dava-se início à preparação de mais uma expedição contra o quilombo de São Sebastião, também na região do Turiaçu. Novamente porque, antes, em março, por requisição do Juiz de Direito da Comarca de São Bento, já tinha sido enviada uma tropa com o "fim de reprimir qualquer agressão dos quilombolas" do São Sebastião, que aliás era próximo daquele denominado Braço do Laranjal. Como era "época do processo eleitoral" e por ter os quilombolas "em presença da força armada retraído-se para o centro das matas", houve a desmobilização temporária daquela força militar. ${ }^{8}$ Preparação de tropas anti-mocambos mais parecia uma rotina a repetir-se no início de cada ano e/ou quando um novo administrador assumia a presidência da província maranhense. Não raras vezes, ordens, autorizações, discussões de estratégias e preparativos começavam durante uma administração e o efetivo envio da expedição só acontecia na administração seguinte. Era o que acontecia naquela ocasião. Tinha assumido a província o senador Francisco Maria Corrêa de Sá e Benevides em substituição ao também senador Frederico de Almeida e Albuquerque. Ao que parece possuíam como semelhança a filiação ao partido conservador e a avidez por destruir mocambos, principalmente

\footnotetext{
${ }^{8}$ BNRJ, Relatório do Exmo Sr. Presidente de Província, Frederico de Almeida e Albuquerque, 1876, pp. 12-3
} 
aqueles de Turiaçu. Sá e Benevides apenas dava prosseguimento às ordens e providências quanto a uma "diligência, de há muito projetada e incessantemente reclamada" por fazendeiros e autoridades de São Bento e Viana, para dar fim "a um formidável quilombo" localizado "do outro lado do rio Turi". 9

Logo na manhã de 5 de novembro partia uma força militar. Composta por 50 praças e alguns oficiais, constituía-se numa tropa de "primeira linha". Como comandante tinha o major Honorato Cândido Ferreira Caldas, do $5^{\circ}$ Batalhão de Infantaria. Havia sido "incumbido" de tal diligência pelo presidente da província anterior, Almeida e Albuquerque. A expedição seguiu inicialmente de São Luís para o município de Alcântara. Foi para ali tentar destruir um mocambo. Esse pequeno desvio de rota não constituiria algo de extrema necessidade naquela ocasião, ou então, uma manobra militar para treinamento daquela força expedicionária. Fazia parte de um plano previamente traçado em comum acordo com o presidente e o chefe de polícia da província. Representava uma estratégia ou, nas palavras do major Ferreira Caldas, "uma ligeira digressão" que tinha o objetivo "se não de bater um pequeno mocambo que lhe consta existir" em Alcântara, pelo menos "distrair para esse lado as vistas indiscretas que porventura pudessem malograr o bom êxito" daquela expedição contra o quilombo de São Sebastião, na região de Turiaçu. ${ }^{10}$

As autoridades já bem sabiam que os quilombolas da região do Turiaçu estavam divididos em vários mocambos entre grandes e pequenos e contavam com a proteção de uma vasta rede de comunicação e comércio - com cativos nas senzalas, vendeiros e lavradores -- que os mantinham informados sobre qualquer movimentação de tropas. As "vistas indiscretas" a quem se queria desviar a atenção podiam ser tanto cativos e vendeiros como alguns fazendeiros e autoridades que poderiam mesmo não ter muito interesse na destruição desses quilombos.

Realizada a primeira parte do plano, a expedição só partiu efetivamente para a região do Turiaçu em 24 de novembro. Não seria a primeira vez que providências para destruir o quilombo de São Sebastião seriam tomadas. Quatro anos antes, nos primeiros dias de 1873, o chefe de Polícia informava ao então presidente de província interino, Silvino Elpídio Carneiro da Cunha, sobre a "necessidade de destruírem-se todos os quilombos, que são o terror dos povoados e das fazendas próximas" e a "conveniência de destroçar-se o quilombo de São Sebastião". ${ }^{11}$

\footnotetext{
${ }^{9}$ Ver: "Relatório apresentado ao Commendador Doutor Francisco Maria Corrêa de Sá e Benevides, Presidente da Província do Maranhão, pelo Major Honorato Cândido Ferreira Caldas, em 13 de janeiro de 1877, dando conta dos resultados conseguidos pela expedição destinada a destruir o Quilombo do Turi". Meus agradecimentos a Mundinha Araújo, diretora do Arquivo Público do Maranhão que me apresentou este relatório em 1994. Ver a transcrição em anexo

${ }^{10}$ Cf. APEM, Relatório..., fl. 1 a 1v.

11 Ibid., fl. 2
} 
A força expedicionária seguiu direto para o lugar chamado Três-Furos. Ali encontrou com o subdelegado de polícia de Turiaçu e mais um oficial da Guarda Nacional. Ainda levaram mais seis homens como voluntários. Estes foram prontamente incorporados, posto que "de grande proveito e até de necessidade", uma vez que eram "homens práticos em cortar mato" "conhecedores daqueles lugares e aptos para o serviço de transporte". Desses voluntários, Antônio Gabriel Ramalho acabaria desempenhando um importante papel nessa diligência. Não só porque tinha noção exata dos caminhos e descaminhos daquelas matas do Turiaçu, mas igualmente já conhecia alguns quilombolas locais. O contato inicial com estes deu-se por acaso. A tropa pernoitou em Três-Furos. Ali - sob a guarda de alguns soldados - ficou parte da bagagem militar. Uma "casinha" serviu para "depósito de gêneros". Um "casquinho" também subiu o rio, margeando-o. Uma pequena "montaria" logo seria avistada com os quilombolas. Os primeiros contatos ocorreram em meio a desconfianças e temores. Tentou-se a aproximação. O "casquinho" com dois soldados e o voluntário Ramalho tentaram alcançar a canoa com seis quilombolas. Estes últimos logo procuraram a margem do rio para um rápido desembarque, o que aconteceu. A canoa foi abandonada. Durante a perseguição ao longo da margem esquerda do Turiaçu, os quilombolas, porém, deixaram cair na água uma de suas espingardas. Voltaram para resgatá-la. Sem perceber que a mesma havia caído no rio passaram a insultar os tripulantes do "casquinho" que também já tinham alcançado a margem daquele rio. Dos insultos seguiram-se "expressões coléricas e mesmo ousadas, passando depois a ameaças de fogo". Os tripulantes do "casquinho" tentaram explicar o acontecido com a espingarda e isto "sem darem sinal algum de perturbação e nem importância a tais ameaças". ${ }^{12}$

Com tal aproximação tentaram-se as primeiras conversações, visando acordos a respeito da possível rendição dos quilombolas do São Sebastião. Entre aqueles quilombolas, o voluntário Ramalho reconheceu "achar-se ali, entre os 6, o governador do quilombo, de nome Daniel". Apelando para a memória desse chefe quilombola, lembrou-lhe que com ele em "outrora se havia encontrado em pescaria". Com menos desconfianças, Ramalho e os outros dois soldados passaram a tentar convencer Daniel e seus quilombolas a entrarem em contato direto com o major comandante Ferreira Caldas. Como convencimento, garantia que "não havia intenção hostil contra ele e seus companheiros". Ao invés disso, o governo, através da pessoa do major, tinha o objetivo de "promover toda a sorte de benefícios" aos quilombolas de São Sebastião que se rendessem.

Daniel aceitou, pelo menos, a proposta para uma conversação. Escolheu o lugar e impôs condições. O dito comandante deveria ir ao encontro com poucos soldados. Sabedor desse prévio

\footnotetext{
${ }^{12}$ Ibid., fl. 3v, 4 e 4v
} 
acordo, o major Ferreira Caldas logo foi "arrebatado de alegria". Como ele mesmo relatou posteriormente ao presidente da província Sá e Benevides, tal notícia o fez "antever desde logo o quadro risonho de um resultado duplamente glorioso para a comissão". Preparou-se, então, para "ir falar a Daniel". Além de seu ordenança, iria apenas em companhia do subdelegado Sá e do alferes Reis. Deixaria as tropas no acampamento em Três-Furos sob o comando do tenente Rodrigues Bayma. ${ }^{13}$

Para transportar essa comitiva foi necessário conseguir um barco maior. Soldados voltaram à margem do rio onde tinha ficado a canoa utilizada pelos quilombolas. Tudo foi feito com precaução, pois não poderia haver "açodamento que por ventura pudesse levar o rei dos quilombolas a atribuir-se a importância de uma imposição, ou por outro lado, a conceber alguma desconfiança fatal". A tal comitiva seguiu para o local indicado. Lembrou o major Ferreira Caldas tanto "a cautela de levar a espada", posto em hora "tão adiantada da noite e em tais lugares", como de também ir todo "uniformizado, isto é, fardado com as competentes insígnias, talim com pasta, banda, etc". ${ }^{14}$ Ao revelar tais detalhes ressaltava: "faço menção desta circunstância, que em si nada tem de notável, por ter ela de algum modo concorrido para que as cousas tivessem o desfecho que tiveram". De fato, a utilização de fardas - e antes disso - o conhecimento de que a força militar enviada era comandada por um oficial do exércitos - teve influência decisiva na disposição dos quilombolas em negociarem sua rendição ou pelo menos conversarem sobre essa possibilidade. Tropas do império significavam as decisões do Imperador, ou seja, a lei. Isso tinha um significado mais amplo naquele contexto.

Fugitivos e quilombolas desconfiavam e muito das autoridades provinciais. Além de serem - via de regra - seus antigos senhores e/ou de seus pais, eram fazendeiros escravistas da região que pagavam as despesas e comandavam a Guarda Nacional em expedições reescravizadoras. Não havia por que confiar nelas. É certo que quilombolas tinham alguns lavradores e até fazendeiros e autoridades que -- em alguns momentos e circunstâncias -- podiam protegê-los. Porém, nem sempre essas alianças eram confiáveis. Havia também um jogo político partidário sempre presente, que tinha como palco o noticiário da imprensa. Liberais e conservadores faziam acusações mútuas nos jornais locais. Despreparo das tropas, falta de providências, escassez de recursos e procedimentos negligentes da polícia (e política) provincial eram temas recorrentes no que diz respeito aos quilombos do Maranhão. E isso já durava décadas. (GOMES, 2003)

\footnotetext{
${ }^{13}$ Ibid., fl. 4v a 5

${ }^{14}$ Ibid., fl. 5 a $5 \mathrm{v}$
} 
No contexto da expedição contra o São Sebastião, quilombolas da região do Turiaçu pareciam ter a noção exata de que, se houvesse alguma possibilidade de negociação das suas rendições e consequentes liberdades, esta deveria ser acordada junto às autoridades do Império. Não porque essas fossem mais bondosas, porém tinham a força da Lei e do rei ao seu lado. O major Ferreira Caldas talvez não tenha percebido o significado político que os quilombolas investiam naquela negociação. De qualquer maneira, ficou nítida para ele a importância de estar negociando enquanto uma autoridade do governo imperial, ou seja, vinda da capital São Luís. Indagando o quilombola Dario como seus companheiros no mocambo receberam a ideia quanto à iniciativa e proposta de entrar em conversação com Daniel para que se entregassem, soube do mesmo que no início "todo o povo fez cara feia e muita gente foi logo saindo". No quilombo, a desconfiança quanto ao "branco" militar que vinha negociar era total. Só mudou quando foi avisado que "o branco não era daqui da província, que era um branco do Império (chamavam província ao mocambo e às vilas mais próximas, e Império a esta capital) pois tinha visto os dourados e a facha do Imperador (naturalmente referia-se aos galões e à banda), o negócio foi agradando". ${ }^{15}$ A percepção política dos quilombolas era clara. Negociar com um "branco do Império", entre outros significados, consistia em fazer valer os seus direitos, inclusive aqueles inscritos na lei.

A tentativa de negociação prosseguiu. O major Ferreira Caldas e sua comitiva encontraram-se com Daniel. Dirigiram-se para o "alto da ribanceira". Ali se achavam outros quilombolas. Todos armados. Começaram as negociações. Argumentos de ambos os lados. Primeiro veio a proposta do referido major. Argumentava no sentido de os quilombolas "abandonarem o centro dos matos e deixarem aquela vida selvagem". Isso era "conveniência" para eles, visto as "privações que sofriam" e que "andavam constantemente sobressaltados com os índios". Além disso, justificaria o major negociador sobre "o favor da lei de 28 de setembro de 1871 " e as vantagens que esta trazia. ${ }^{16}$

Esses termos para um acordo, feitos pelas autoridades, são reveladores. De início, percebe-se a ideia de "vida selvagem" dos quilombolas versus "vida civilizada" dos escravos que continuavam nas senzalas. O "selvagem" ai não era só fruto de uma vida no meio da floresta, mas também longe da disciplina dos senhores e do controle do poder público. De outro modo, sabiam as autoridades que alguns mocambos da região do Turiaçu passavam, no momento, por um período de penúria e fome em virtude das campanhas anti-mocambos das décadas de 60 e 70 e também dos conflitos com os grupos indígenas, uma vez que acabaram cada vez mais

\footnotetext{
${ }^{15}$ Cf. APEM, Relatório..., fl. 5v a 6

${ }^{16}$ Ibid., fl. 6 a $6 \mathrm{v}$
} 
empurrados para o interior. Assim como os quilombolas maranhenses na insurreição de Viana (1867) forçaram a sua liberdade porque sabiam que o poder público e senhores estavam enfraquecidos por lutas externas e internas, agora era a vez das autoridades. Estas também usaram o raciocínio da lei. A mesma de 1871, que tanto preocupou os fazendeiros, movimentou os políticos e deu o que pensar e agir aos escravos em vários cantos e províncias do país. (GOMES, 2003)

Alegaram - na perspectiva da lei - a importância da matrícula dos escravos. A partir dela os fazendeiros comprovariam seu direito de propriedade. E também o poder público poderia cobrar impostos. Por sua vez, os quilombolas, retornando à condição de escravos, poderiam apresentar seu pecúlio para a obtenção da alforria. Isso tudo seria feito com a garantia da lei do Império e não mais somente com a vontade senhorial. Dizia que seria fácil conseguir o dinheiro para esse pecúlio. Ficava implícito aqui que os escravos podiam consegui-lo através de uma economia própria. Isso, é certo, não constituiria novidade para os aquilombados no Turiaçu. Há muito tinham uma rede econômica que ligava a sua economia com aquela dos cativos assenzalados, ainda tendo a cooperação de outros setores da sociedade envolvente (GOMES, 2002, p. 26-31). Por fim, enfatiza que caso permanecessem nas matas, as perseguições reescravizadoras prosseguiriam e "mais tarde ou mais cedo" acabariam capturados.

Daniel, o chefe do quilombo, também fez as suas ponderações. Admitia que eles, quilombolas, estavam, de fato, "muito desgostosos da situação (o mocambo) por causa dos gentios". Disse que há quatro anos já tinha "apresentado a idéia" de estrategicamente se entregarem ao "governo do império", quando os ataques indígenas recrudesceram. Mas não houve adesão ou entusiasmo dos quilombolas, "mesmo porque todos têm muito medo de voltar ao poder de seus senhores pelos maus tratos que recebiam". ${ }^{17} \mathrm{O}$ chefe quilombola reconhecia que a situação e a "situação" (o local) dos mocambeiros naquele contexto eram desvantajosas. Ao adentrarem cada vez mais para as matas, fugindo das tropas, quilombolas encontravam com tribos indígenas e também sofriam ataques. Os constantes deslocamentos, igualmente, representavam dificuldade de abastecer um número grande de pessoas em termos de alimentação. Tiveram também a percepção da lei. Já tinham pensado numa rendição negociada. Entregar-se-iam aos seus senhores sob o patrocínio do "governo do império". Desistiram da ideia. Com toda a dificuldade tentaram viver na floresta com sua economia. Nas mãos dos senhores, eles - e seus filhos - se desmanchariam em dor nos castigos e trabalho duro nas lavouras. Seus senhores não perderiam tempo em se vingar dos seus longos períodos de ausência e insubordinação nas matas.

${ }^{17}$ Cf. APEM, Relatório..., fl. 6v 
Havia, entretanto, várias questões implícitas importantes nessa primeira rodada de negociações entre o governo imperial/major Ferreira Caldas e os quilombolas de São Sebastião/chefe Daniel. Primeiro, as tentativas de negociação das autoridades - ao que se sabe, as primeiras - naquele contexto faziam parte, por um lado, de novas estratégias de ação do poder público para combater quilombos, e por outro, de questões específicas do quadro maranhense (FUNES, 1995; FUNES, 1996, p. 467-497). As autoridades não tiveram na ocasião nenhuma preocupação mais humanística para com os quilombolas ou então estavam profundamente preocupadas com a propriedade dos fazendeiros. O que também estava em jogo ali era a valorização das terras do Turiaçu e Gurupi, o controle da região e a produção aurífera das minas. Se de um lado, os quilombolas poderiam ser aliados no desbravamento destas matas, empurrando as tribos indígenas mais para o interior e conhecendo as principais fontes e locais de extração de ouro, igualmente, de outro, representavam uma ameaça a sua economia camponesa. A garimpagem e as redes de comércio clandestinas cada vez mais ampliavam e eram impossíveis de controlar. Se não fosse só isso, a existência de inúmeros quilombos na região continuava consistindo num foco quase secular para as permanentes fugas de escravos. Tal situação representava a insubordinação da massa escrava na região, alcançando outras áreas do Maranhão e atravessando a fronteira com o Pará. (BEZERRA NETO, 2001)

Fazendeiros reclamavam, moradores das regiões próximas pediam providências e em algumas situações abandonavam suas casas e lavouras, jornais aproveitavam-se disso para intrigas políticas. Acusações e denúncias pipocavam. Enquanto isso, recursos municipais, provinciais e imperiais nunca eram suficientes para suprir os gastos quase anuais e cada vez maiores com a realização de expedições punitivas. Também com a lei de 1871, as autoridades imperiais reconheceram a insatisfação dos senhores e o aumento da criminalidade escrava em todas as províncias (CARVALHO, 1988, p. 61-83; CONRAD, 1976, p. 88-111). No Maranhão, o problema dos mocambos era a uma só vez agudo e crônico. Planos e estratégias diversas tinham sido tentados. Não foi por outros motivos que, no final da década de 70, a polícia da província começava a falar em "meios suasórios" nas medidas anti-mocambos. O sinônimo disso para os períodos anteriores foi - via de regra - muita truculência, pólvora, munição e intolerância (FUNES, 1995; GOMES, 1995).

Da parte dos quilombolas, uma negociação também naquele contexto poderia ser tentada. Igualmente perceberam a mudança de atitude das autoridades. E antes dela viram como as forças militares tentaram a todo custo destruir seus mocambos. Os termos de negociação é que continuavam duvidosos. Voltando ao poder de seus senhores, queriam a garantia na lei de que poderiam obter suas alforrias. Mais que isso. Certamente contavam que uma vez livres poderiam 
decidir o que fazer e assim retornariam para a floresta para cuidarem de suas roças, proverem suas famílias, refazer suas alianças e extrair ouro das minas. Isso era tudo que as autoridades tanto do império como da província - não queriam.

No São Sebastião, as tentativas de negociação prosseguiriam com outros lances e desdobramentos. Daniel e os quilombolas, depois das "exortações" do major Ferreira Caldas das quais "superabundou" o subdelegado que o acompanhava -, "pareceram reflexionar um pouco". A princípio Daniel pediu tempo. Alegou que a chegada da tropa assustou os quilombolas. Eles, que já estavam espalhados em seus mocambos numa grande área fora o centro e o principal quilombo São Sebastião, tinham-se dispersado ainda mais. Disse que somente "com um ou dois meses" conseguiria reunir todos os quilombolas e depois dar a decisão definitiva. O major Ferreira Caldas de pronto não concordou. Mostrou logo que de político tinha muito de militar e não aceitava esperar muito. Em vez dos dois meses solicitados, aguardaria quatro dias para que Daniel comunicasse e reunisse os quilombolas. Estava quase deixando a sua decantada e perseguida cautela de lado. Depois de uma breve lição de ciência política para os quilombolas, o tom dos seus "meios suasórios" ficou mais enfático. Pediu a Daniel que ele próprio o guiasse até os mocambos principais do São Sebastião. Acreditava que a sua presença iria "convencer" os quilombolas quanto àquele acordo. Daniel não pareceu entusiasmado pela proposta, mesmo considerando a sua "liberdade" e de toda a "sua família". Não queria dar já uma resposta. $\mathrm{Na}$ frente do dito major pediu a opinião de alguns quilombolas que o acompanhavam: "dois responderam que estavam pelo que ele quisesse e os demais conservaram-se calados". Resolveu consultar também outros mais quilombolas "ali atrás num lugar chamado Laranjal", pois "tinham eles um grande piquete de prontidão". A decisão final ficaria mesmo para o dia seguinte. O major Ferreira Caldas recuou e teve que aceitar. Prevaleceria o espírito de cautela que quase tinha abandonado. Relataria: "era a bem do meu plano dar-lhe a entender que da parte deles, mais do que da minha, devia haver todo o empenho em levar-se a efeito esta combinação". ${ }^{18}$

A comitiva do governo imperial voltou para o acampamento das tropas em Três-Furos. Como era madrugada, foi acompanhada por dois quilombolas. Esperariam a resposta até às 10 horas da manhã do dia seguinte. Esta, porém, não chegou. E era um domingo. O major Ferreira Caldas temeu que a negociação tivesse fracassado. Depois de alguns conselhos dos oficiais que comandava decidiu voltar ao Laranjal, local de encontro da primeira rodada de negociações. Quem faria isso seria o tenente Bayma "a titulo de passeio, acompanhado apenas de dois voluntários que sabiam pescar à flecha". Temeroso quanto ao desfecho de sua "combinação",

${ }^{18}$ Cf. APEM, Relatório..., fl. 8 
queria "ver se encontrava Daniel e podia colher alguma" notícia. Entretanto, nem foi preciso forjar pescarias. Já no caminho para o Laranjal encontrou-se Daniel. Trazia "ótimas notícias". O major Ferreira Caldas seria guiado por ele até o centro do quilombo. Como condição deveria levar "poucas praças a fim de não assustar a sua gente". Uma outra comitiva foi preparada para entrar no quilombo de São Sebastião. Mais precauções seriam tomadas. Alguns soldados foram deixados no Três-Furos "para vigiar o depósito de gênero e defender aquele ponto, base das operações". O restante da tropa seguiu também para o Laranjal. Como não havia canoas para transportar tantos homens, a tropa seguiu por terra através de "uma picada que os voluntários iam abrindo". Enquanto isso, o major Ferreira Caldas e seu ordenança, o tenente Bayma, um capitão da Guarda Nacional - residente ali próximo em Pinheiro - o "demais dois ou três paisanos, moradores no caminho", seguiram de canoa ao encontro de Daniel. Como o combinado, Daniel já o esperava. Em sua companhia estavam somente quatro quilombolas. Ali esperaram toda a tropa chegar. Seguiriam todos juntos para o mocambo.

$\mathrm{Na}$ caminhada pela floresta, a tropa estava disposta estrategicamente com guias à frente $\mathrm{e}$ soldados na retaguarda. Mais uma vez Ferreira Caldas aliava seus dons políticos com aqueles de dedicado estrategista militar. Ainda que não fossem revelados, deveria haver muitos medos e temores rondando aquela diligência. Não só da parte de seu comandante. Os outros oficiais, voluntários e praças talvez temessem que os quilombolas e Daniel estivessem preparando uma grande emboscada, atraindo-os para o interior da floresta. Todo cuidado era pouco. É bem verdade que até o último minuto o major Ferreira Caldas acreditou mesmo na possibilidade de uma emboscada. Durante o trajeto para o quilombo não poucas vezes desconfiou de Daniel. Isso aconteceu quando "passado algum tempo", ele reparou que a diligência "pouco" tinha avançado "em razão das continuadas voltas". Notou mesmo "ser completamente ínvio o rumo" tomado. Asseverando-se de suas suspeitas, ouviu o próprio ex-quilombola Militino. Este não reconheceu aquele caminho como o "que viera quando fugira do quilombo". Suspeitas e temores voltaram a rondar, dando dicas de como eram vistos os quilombolas. Estariam eles entre a "selvageria" e a "civilização".

Ao mesmo tempo em que temia, o major Ferreira Caldas tinha que confiar em Daniel. Para este, aliás, já havia usado o adjetivo de "preto inteligente e bem intencionado". De qualquer forma, quilombolas, assim como negros, escravos e africanos, era de uma outra "espécie de gente". Mais que isso, asseverava: "nessa espécie de gente um raio só de desconfiança basta para destruir uma crença inteira ou derrocar o ídolo de suas íntimas adorações". Os temores desse major e seus ajudantes também podem ser explicados pelo fato inusitado daquela "combinação". Depois de inúmeros ataques aos quilombos de Turiaçu, os medos de insurreição e o próprio 
levante dos quilombolas, uma tropa militar entraria num desses quilombos sendo guiada e com a anuência de seu chefe quilombola. Podia parecer às vezes difícil de acreditar (GOMES, 2003).

A caminhada para o quilombo de São Sebastião foi longa e árdua. Durou mais que um dia. A comitiva pernoitou "dentro de um círculo de sentinelas", prevenindo-se "de alguma tentativa dos índios". A marcha prosseguiu logo na manhã seguinte e segundo Daniel o quilombo já estava "em meio do caminho". A dureza daquela jornada foi logo acusada pelo major, posto que estava "bastante incomodado de um calo no calcanhar do pé esquerdo". Entretanto, valorizando o seu papel de comandante militar, comentou em sua narrativa que "fazia das fraquezas forças, sem dar o menor sinal de sofrimento".

Com a aproximação ao quilombo houve mais negociações. Daniel pediu que a tropa se mantivesse distante e que somente ele e o major entrariam no povoado quilombola. $\mathrm{O}$ major concordou, mas deixou de sobreaviso seus subalternos para qualquer surpresa. Em "particular" combinou com seu oficial imediato que caso "ouvisse um tiro isolado, seguisse a passo de caminho" para o quilombo, mas "se ouvisse dois, marchasse incontinente em acelerado". Daniel também tinha sua combinação de tiros dados para o alto visando entrar no quilombo com a comitiva sem que isso fosse percebido como uma invasão forçada. A comitiva do major Caldas entrou no quilombo. Sua descrição do quilombo é deveras etnográfica para um militar talvez só acostumado com tiros, perseguições e escaramuças no que diz respeito aos quilombolas. Começou traçando o local "colocado no centro (que era ao mesmo tempo o ponto culminante) de um belo descampado circular, de mil braças de diâmetro mais ou menos, terminando pelas roças que acompanhavam toda a circunferência". ${ }^{19}$ Visto o palco do quilombo, passou a descrever o cenário econômico montado, com "casas" de farinha, engenhocas etc. Tinham uma base econômica para abastecimento e troca, produzindo farinha, cera, fumo e aguardente. Na descrição de Ferreira Caldas percebe-se também como os quilombolas escolhiam o lugar para seus mocambos. Vale lembrar que parte destes quilombolas era remanescente do quilombo São Benedito do Céu atacado em 1867. Não escolheram qualquer outro lugar. Mas aquele próximo a um igarapé com água o ano todo e igualmente protegido pela floresta. Mais que isso, após quase dez anos, tinham reedificado suas casas e reerguido suas bases econômicas.

O ineditismo maior da narrativa do major Ferreira Caldas, no que diz respeito aos ataques aos quilombos, aparece quando ele descreve os habitantes no seu interior. É certo que, em não raras ocasiões, forças militares - não apenas para o Maranhão - entravam dentro dos quilombos. Quase sempre os encontravam vazios e/ou abandonados. Ou quando muito com poucos quilombolas em retirada. Agora uma autoridade militar conseguia adentrar num considerável

\footnotetext{
${ }^{19}$ Cf. APEM, Relatório..., fl. 10 e 10v
} 
quilombo. E foi nessa circunstância que pôde descrevê-lo, seus habitantes e um pouco da sua vida interna. Descreveu que logo "ao penetrar no recinto do mocambo" viu chegar quilombolas armados "por toda a parte", formando "nesse todo bélico um perfeito contraste com a falta quase absoluta de decência no traje". Apontaria os contrastes desta sua visão, pois de um lado viu "um homem gigante, musculoso, verdadeiro filho das selvas", de outro, a figura de um negro "pobre velho", "um simulacro de gente, um esqueleto", isto "apoiado a um bastão, reduzido a maior penúria de magreza". ${ }^{20}$

Suas descrições ganhavam força quando acompanhadas de reflexões. Era uma narrativa ao mesmo tempo na primeira e terceira pessoa. Seria ao mesmo tempo o narrador, o comentarista, o espectador e o principal protagonista daquela trama. Tentava, numa fala etnocêntrica, revelar suas próprias percepções a respeito dos quilombolas, utilizando imagenssímbolos, metáforas e metonímias. Afirmaria ainda sobre o interior do quilombo:

\begin{abstract}
"lá no fundo a esbelta de uma Santa Cruz, com os braços bem abertos, parecendo pedir preces em favor dessas infelizes criaturas, nossos semelhantes, e cuja raça já tem de sobejo pago o penosíssímo tributo de ser a vergonha da humanidade e especialmente do Brasil. Oh, em face de tão variado e tocante espetáculo fiquei absorto e extasiado...; num momento cerrei externamente os olhos e olhei-os dentro da alma para dirigir de louvor ao todo poderoso, criador do universo, suplicando-lhe de abençoar a missão que ali me levara...(...)"121
\end{abstract}

Talvez fosse o caso de se conhecer melhor quem era o major Ferreira Caldas para se fazer a arqueologia deste tipo de discurso. Não muito sabemos sobre ele. Era um jovem ou velho militar? Teria combatido na guerra do Paraguai? Na verdade, Honorato Cândido Ferreira Caldas era um militar de 35 anos, mas já com muita experiência. Natural da própria província do Maranhão, entrou para o Exército, em 1859, com apenas 17 anos. Lutou na guerra do Paraguai, tendo sido condecorado com medalhas de bravura. (SACRAMENTO BLAKE, 1937, p. 514) ${ }^{22}$ Naquela ocasião, mesmo como militar - quiçá só acostumado a batalhas e contendas -, parecia tentar construir um discurso bem dentro do roteiro das ideias liberais da época. Se não tinha o fôlego hercúleo acadêmico de um Brandão Jr., sua fala tinha o tom humanístico do positivismo cristão, ora liberal, ora conservador que misturava as ideias-força de "civilização" e "evolução". (AZEVEDO, 1997, p. 44-47; CONRAD, 1976, p. 102-3) ${ }^{23}$ Para além das certezas das "ciências"

\footnotetext{
20 Ibid., fl. 11

${ }^{21}$ Ibid., fl. $11 \mathrm{v}$

${ }^{22}$ Foi reformado em 1890 como general de Brigada. Também ganhou os títulos de Oficial da Ordem da Rosa e Cavalheiro da Ordem de Aviz.

${ }^{23}$ Ferreira Caldas publicou com 52 anos a obra: "A Deshonra da República: Artigos publicados e memórias inéditas do cárcere, sobre a revolta da esquadra e o governo do Marechal Floriano Peixoto pelo general de Brigada Honorato Caldas (preso a 23 de outubro de 1893 e solto a 10 de agosto de 1894 sem nota e sem processo e julgamento algum)". Rio de Janeiro, 1985, 200 pgs.
} 
da natureza e econômicas havia os "sentimentos". Ferreira Caldas parecia mesmo querer encarnar nas suas ações e pensamentos o poder moderador imperial. Este era tanto temporal como espiritual. Vale lembrar que esse discurso de Ferreira Caldas aparece num relatório enviado ao presidente da província vários dias depois de realizada esta sua expedição. Carregar aqui ou acolá nas tintas, esmiuçar determinados detalhes e construir uma dada ordenação cronológica ou casual dos fatos podia fazer sentido num momento em que elites políticas, fazendeiros, opinião pública (através da imprensa), autoridades provinciais e aquelas do império tentavam sair de um impasse quanto ao fim da escravidão no Brasil num período senão próximo, pelo menos não muito distante.

Depois das primeiras impressões de ambos os lados, as negociações prosseguiriam. Isso porque quilombolas também devem ter ficado impressionados com a presença no interior de seu quilombo de um oficial do império, todo paramentado com farda, insígnias etc. Infelizmente sobre tais possíveis impressões nada conhecemos. Mais uma vez Ferreira Caldas tentaria convencer aos quilombolas para que se rendessem. Argumentou em nome de "Deus", chamou-os de "filhos", dizia-se "protetor" e desejou o "bem estar" de todos. Isso tudo fez em meio a "uma desconfiança em alguns", "perplexidade em outros" e um "caráter de resignação em muitos". De qualquer forma, notaria "em todos uma viva expressão de respeito". Quanto à presença de força militar, afirmava que estava ali para garantir a proteção aos quilombolas "contra os gentios". ${ }^{24}$

Daniel deu autorização para que toda a tropa ficasse aquartelada no interior do quilombo. O local escolhido (pelos próprios quilombolas?) foi a "capela velha". Para seus soldados, deu reiteradas ordens para que ali permanecessem em "harmonia". Permitiu a "negociação" entre os quilombolas e soldados, "mas com a condição de virem a minha presença, comprador e vendedor". Temia que os motins e desordens na tropa originassem mais desconfianças dos quilombolas. Mesmo assim estabeleceu todas e "certas condições de segurança peculiares aos regimentos militares". Quanto ao aquartelamento no quilombo, disse ainda que:

"Era uma casinha recentemente concluída, bem construída e no melhor estado de asseio possível; Angela, a rainha do quilombo (não é casada com Daniel, mas vivia como tal em sua companhia e tem dele um casal de filhos ingênuos), apresentou-se imediatamente com redes para todos nós, de algodão é verdade, porém decentes e bem tecidas, e desde então tornou-se incansável no empenho de proporcionar-nos as comodidades compatíveis com a exiguidade dos seus recursos, sendo ela própria a nossa cozinheira e servente até deixarmos o mocambo". 25

Ferreira Caldas já estava exausto e "tão fatigado". A longa e dura caminhada e a "compressão da botina" tinha-lhe proporcionado, além da inflamação do calcanhar, "um penoso

\footnotetext{
${ }^{24}$ Cf. APEM, Relatório..., fl. 11v

${ }^{25}$ Ibid., fl. 12 e $12 \mathrm{v}$
} 
incômodo, o germe de uma erisipela talvez". Mas tudo valia a pena. Como "compensação" de seu esforço - ressaltava - "acabara de meter uma lança em África". Afinal tinha conseguido tomar "posição dentro do famigerado quilombo do Turi, todo povoado, sem o mais leve incidente desfavorável".

Apesar da boa receptividade e hospitalidade dos quilombolas de São Sebastião, o dito major até aquele momento não havia conseguido garantir a sua "combinação". Os quilombolas aceitaram os termos de rendição? Nada estava decidido. Desse modo, "não era tempo ainda de repousar tranqüilo à sombra desse troféu de paz". Ao que parece Daniel tentava - como proposto - convencer a todos os quilombolas.

Dissidências logo apareceriam. Um dos seus quatro "contra-capitães", o quilombola Sotero, foi o primeiro a se retirar do quilombo, levando "consigo vinte e tantas pessoas". Outros - ao que consta - pareciam querer seguir o mesmo caminho, uma vez que "conservavam a bagagem escondida no mato". O "troféu da paz" parecia ser de cera e estar se desmanchando nas mãos do político e militar Ferreira Caldas. O que fazer? Tinha a perfeita percepção de que era "na escolha do meio a empregar e no tino de sua aplicação" que se encontrava "todo o segredo da arte, e com ele toda a glória da empresa".

Qualquer decisão precipitada ali seria mais do que complicada. E foi essa a digressão que fez no seu relatório. Mesmo estando com sua força dentro do quilombo, ordenar ali um ataque à noite seria - "a falsa fé" - desastroso. Tal desastre traria os piores resultados do ponto de vista moral e militar. Primeiro porque seria "uma dupla traição e vergonhosa covardia". Segundo porque seu "resultado seria talvez nulo" e o pior, trazendo "conseqüências funestíssimas". Mesmo em melhor posição, um ataque acabaria em "mortes, ferimentos, etc". Além disso, quilombolas alarmados, tratariam logo de fugir. Bem se sabia que eram "velozes como a corça e senhores do terreno". Persegui-los na floresta era impensável. Além das dificuldades, a força militar era reduzida para tal empreitada. E cada vez mais diminuíra com as doenças que já haviam acometido alguns soldados. Entre centenas de quilombolas apenas acabariam capturados "uns 20 ou 30, quem sabe com quantos desastres". Caso isso ocorresse teria o efeito de "uma completa derrota".

Apenas ficar estacionado com tropas no quilombo também não era a solução. Ainda que não se pudesse medir o esforço de Daniel para convencer os outros quilombolas, vários deles estavam abandonando seus mocambos, indo para outras regiões. Quando a "rendição" fosse conseguida haveria apenas 1/3 dos quilombolas para executá-la. Nesse caso, "mais que uma incúria, mais que um erro crasso, seria verdadeira e criminosa imbecilidade". Era tudo ou nada. 
Ferreira Caldas adotaria uma decisão - como mesmo revelou - de "bom senso". Daria como decidida a "rendição" dos quilombolas e começaria prontamente a preparar a viagem de retorno":

\begin{abstract}
"deixá-los continuar a trazerem suas respectivas armas; a título de prevenção contra os índios; organizar uma polícia secreta entre eles mesmos; tratar com o maior empenho de curar os doentes; empregar toda a solicitude e diligência em fazer reinar a alegria no mocambo, repetindo á um e á outro e melhoramento de vida que iam ter com tais elementos incutindo a fé no ânimo de todos, sem nunca perguntar-lhes por seus senhores, etc, ir suavemente preparando as cousas para a breve transformação". ${ }^{26}$
\end{abstract}

Apostou alto nessa sua estratégia. O importante ali era a dissimulação. Sem escrever, talvez tivesse pensado que os quilombolas não deveriam perceber como estava interessado e ávido para capturá-los. Era só nisso que pensava. E assim foi feito. Participou de "festas" promovidas pelos quilombolas e os presenteou com "uma rês viva para a carneada", "dois cantis cheios de aguardente", "gêneros alimentícios" e o "resto dos medicamentos". Um outro fator pouco mencionado favoreceu, porém, a decisão daqueles quilombolas liderados por Daniel a se entregarem. Parecia estar havendo uma epidemia de "febres" no quilombo. Muitos quilombolas e já alguns soldados estavam sofrendo da mesma. A viagem de volta tinha que ser rapidamente preparada e efetivada. Ferreira Caldas faria mais. Prometeu comprar os produtos da economia dos quilombolas. Poderiam levar - caso quisessem - um pouco de farinha. O restante seria comprado "assim como arroz, milho, galinhas, patos e alguma coisa mais que tivessem, a fim de não ficarem prejudicados". Quanto às armas, poderiam trazê-las em seu poder. Seria uma "cautela necessária contra as tentativas traiçoeiras dos índios". Entretanto, deixou patente para os quilombolas que estes não poderiam entrar armados na vila do Pinheiro. Logo que atravessassem o outro lado do rio Turiaçu, "cada qual trataria de vendê-las". ${ }^{27}$

Antes de partirem - a comitiva e os quilombolas -, soube-se que "um outro contracapitão de nome Ernesto tratava de formar um partido muito às surdinas, contrário às idéias de Daniel". Providências foram imediatamente tomadas. Já se fazia sentir, então, o efeito da "polícia secreta" entre os próprios quilombolas que Ferreira Caldas mencionava anteriormente. Por certo, durante aquele aquartelamento no quilombo, soldados e quilombolas tornaram-se "próximos" o bastante. Além do mais, alguns voluntários - como vimos um tal Ramalho, por exemplo - já haviam tido "comunicações" com esses quilombolas. A tal "polícia secreta" deve ter funcionado bem nesse contexto. Enquanto isso Daniel permaneceria mais para o interior das matas, convencendo outros quilombolas em seus mocambos mais afastados.

\footnotetext{
${ }^{26}$ Cf. APEM, Relatório..., fl. 13v a 14

${ }^{27}$ Ibid., fl. $14 \mathrm{v}$
} 
Quase preparado para o retorno, Ferreira Caldas voltaria a ter notícias de novas "resistências" de alguns quilombolas de capitularem com Daniel e seus seguidores:

"pelas 10 horas da manhã mais ou menos, não tendo ainda voltado Daniel, Ângela veio muito reservadamente avisar-me de uns cochichos que ouvira entre tais e tais pretos (indicou-me os nomes) a fim de que eu providenciasse á respeito como julgasse melhor, pois tinha suas razões para desconfiar deles, e acrescentou que alguns outros andavam propalando, que só me acompanharia metade da gente e que a outra metade ficava no mocambo". ${ }^{28}$

Mais uma vez contornaria essa situação. Novamente reuniria os quilombolas para novas conversas e convencimentos. Desta vez tratou logo de desarmá-los, pelo menos aqueles acusados de motins. Deixou claro que sua intenção era partir dali com todos os quilombolas e não somente a metade. De novo lembraria para aqueles que mantinham a vontade de continuar no quilombo que poucas chances teriam contra os índios. Ao que parece, os quilombolas recuaram. Se bem que no dia seguinte se noticiou que mais cinco quilombolas tinham escapado do quilombo.

Finalmente no dia 5 de dezembro a marcha de retorno teve início. Já fazia um mês que essa expedição tinha partido de São Luís, mesmo considerando o tempo gasto no suposto ataque de despistamento a um mocambo em Alcântara. Antes de deixar o quilombo São Sebastião, o major Ferreira Caldas ordenou que as roças e casas fossem incendiadas e que se "demolisse e arrasasse tudo, menos as duas cruzes". Supersticioso ou católico o dito major?

Durante essa marcha de retorno não aconteceram muitas novidades. Apenas ferimentos e a enfermidade de Ferreira Caldas pioraram. Também houve a fuga do quilombola Ernesto, um dos amotinados. Antes de embarcarem num vapor para a vila de São Bento, também o referido comandante mandou "comprar a fazenda necessária para seu vestuário [dos quilombolas]", dando "toda a pressa na prontificação da roupa, visto estarem quase nus e ser uma indecência apresentarem-se em público nesse estado". Os quilombolas ainda seriam batizados e vacinados antes de ficarem presos na cadeia pública de São Luís. Ali chegariam em 29 de dezembro 115 quilombolas. $^{29}$

\section{Culturas quilombolas e a crioulização}

Continuamos ainda sabendo muito pouco sobre a organização interna dos quilombos no Brasil. Sobre os mocambos maranhenses do Turiaçu-Gurupi, podemos, entretanto, levantar algumas questões iniciais. As expedições punitivas conseguiram, ao longo do século XIX,

\footnotetext{
${ }^{28}$ Ibid., fl. 16 a $16 \mathrm{v}$

${ }^{29}$ Ibid., fl. 18 a 22
} 
invadir e destruir dezenas de mocambos e quilombos. Outros tantos logo formar-se-iam. Com um ar de frustração conseguiram apenas invadir mocambos que já estavam abandonados. Era prática dos quilombolas se refugiarem em outros mocambos. Isto não foi só no Maranhão, mas estratégias de várias comunidades de escravos fugidos nas Américas. Também houve casos de enfrentamento mais direto contra tropas reescravizadoras. Quando conseguiram adentrar os mocambos, soldados viram casas, capelas e uma complexa economia. A "grandeza" de alguns mocambos - este é o caso do Maranhão - em termos de quantidade de casas e roças plantadas muitas vezes surpreendiam os oficiais militares que comandavam essas diligências.

Houve casos, porém, em que se falou um pouco mais sobre o que foi visto em alguns mocambos invadidos. Em 1862, nas expedições comandadas contra os quilombos maranhenses do Queimado, do Pacoval e principalmente do São Benedito do Céu, o tenente Máximo Fernandes destacou ter encontrado, entre as várias casas do quilombo, "uma de oração". 30 Afirmaria ainda: "mereceu toda a minha atenção e de toda tropa já pelo tamanho, já pela decência com que estava assentado o altar e já finalmente por causa de uma cruz que estava dentro desta, muitas flores, arcos, etc". Encontraria ali também "quarenta e seis cachorros", os quais achou por bem "distribuir entre os guardas e soldados". ${ }^{31}$

Descrições mais detalhadas sobre a cultura e a religião nesses mocambos maranhenses apareceriam nas expedições enviadas contra os quilombos São Sebastião e Limoeiro, no final dos anos 70. O primeiro seria o nosso conhecido major Honorato Cândido Ferreira Caldas. ${ }^{32}$ No seu longo relatório constariam, aqui ou acolá, algumas evidências da cultura quilombola. No encontro inicial para começar as "negociações" com o "chefe Daniel" e seus comandados, anotou que estes acenderam "um pavio, que sempre os acompanhava, composto de cera de abelha e breu". Com a rodada de "negociações" adiantada, o major Ferreira Caldas, chegando ao quilombo, faria logo a seguinte descrição panorâmica:

\footnotetext{
"58 casas, cobertas de palha e tapadas de barro, na maior parte com portas e janelas de madeiras, sendo 2 denominadas Casas de santo, bem distintas pelas cruzes levantadas em frente, 3 de fazer farinha com competentes fornos, 1 de depósito e cera, outra guardando um alambique de barro, e as demais -- habitação dos quilombolas, porém todas sem simetria alguma, tanto assim que só havia duas ruas menos irregulares -- a de cima e a de baixo --, separadas uma da outra pelo adro da capela velha."
}

\footnotetext{
${ }^{30}$ ANRJ, IJ1 754, Ofícios de Presidentes de Província (MA)/Ministro da Justiça, Ofício do Tenente Máximo Fernandes Monteiro enviado para o delegado de Polícia, Raimundo Benedicto Muniz, 22/02/1862

31 Ibid.

${ }^{32}$ APEMA, "Relatório apresentado ao Comendador Doutor Francisco Maria Correia de Sá e Benevides, Presidente da Província do Maranhão, pelo Major Honorato Cândido Ferreira Caldas, em 13 de Janeiro de 1877, dando conta dos resultados conseguidos pela expedição destinada a destruir o Quilombo do Turi"
} 
Por ser mais convidado do que invasor, Ferreira Caldas, porém, conseguiria ver algo mais. Pernoitando algumas noites em São Sebastião, seria convidado -- com toda a sua tropa -para uma festa: "festejavam nesse dia à São Benedito e vieram-me dizer que o jantar da festa estava pronto". Note bem, o quilombo era o de São Sebastião, mas a festa era para São Benedito. Ferreira Caldas não fez desfeita. Aceitou o convite e foi "com os oficiais assistir a cerimônia que teve lugar dentro a própria Capela (a nova)".

Quem também anotou detalhes sobre a cultura quilombola foram os invasores do quilombo Limoeiro, em 1878. Uma vez foi na primeira expedição, comandada pelo diretor da Colônia Militar do Gurupi, João Manoel da Cunha. ${ }^{33}$ Destacaria logo de início as "trincheiras" que foi obrigado a escalar -- juntamente com sua tropa -- para conseguir entrar no quilombo. Manoel da Cunha disse que eram feitas de "grossas madeiras sem guarnição". Sobre o Limoeiro descreveria:

\begin{abstract}
"(...) têm 91 casas, em cada uma morando três, quatro e cinco pretos com suas mulheres e filhos, e tem mais duas casas destinadas à oração, a que chamam casas de santos; sendo uma com imagens de Santos, e outra onde encontramos figuras extravagantes feitas de madeira, cabaças com ervas podres e uma porção de pedras de que em tempos muito remotos os indígenas se serviam como machados, as quais a maior parte dos mocambeiros venera com a invocação de Santa Bárbara, porém, não passa tudo isto de uma casa de pajés." ${ }^{34}$
\end{abstract}

Temos aqui várias informações convergentes. No São Benedito do Céu, no São Sebastião e no Limoeiro havia "capelas" e "casas de santos" e/ou "casas destinadas à oração". Teve "cerimônia" de festa para São Benedito, e no Limoeiro "veneravam" Santa Bárbara. Falavam também de "tempos remotos" dos indígenas e "casa de pajé". O que estaria acontecendo nesses quilombos? Quais seriam os significados da vida religiosa desses quilombolas?

$\mathrm{Na}$ segunda expedição contra o Limoeiro comandada pelo Capitão Feliciano Xavier Freire Jr., em 1878, mais descrições surgiriam. Esse militar - já presente na primeira diligência comandada por Manoel da Cunha - invadiria o Limoeiro mais duas vezes. Isso porque, antes mesmo de adentrar esse quilombo com sua tropa, "invadiu-o" com olhos indiscretos. Foi na "ocasião de sitiar-se a ranchada". Ali assistiu - ao que se sabe escondido e numa posição privilegiada - a uma "festa de pajés" comandada pelo "chefe" quilombola Estevão. ${ }^{35}$

"Formados os calhambolas em círculo, o preto Bernardo ocupava o centro, e batendo palmas, cantava -- eu já vai no céu, eu já vem do céu -- e os mais faziam coro. Tinham

\footnotetext{
${ }^{33}$ Documentação do APEMA transcrita em: ARAÚJO, Mundinha. A Invasão do quilombo Limoeiro. São Luís, SIOGE, 1998.

${ }^{34}$ Relatório de João Manoel da Cunha sobre a primeira invasão do Quilombo Limoeiro, 24/01/1878, transcrito em: Ibid., pp. 28

${ }^{35}$ Relatório do Capitão Feliciano Xavier Freire Júnior sobre a segunda invasão do Quilombo Limoeiro, 22/05/1878 transcrito em: Ibid., pp. 48-57
} 
Bernardo na sua volta do céu de fingir-se sonâmbulo e, então revelar o futuro; porque tudo lhe havia dito Santa Bárbara com quem havia conversado. Durante esta nigromancia, era Bernardo chamado menino do céu". ${ }^{36}$

Quais os significados das práticas religiosas desses quilombolas? Afinal, havia uma cultura propriamente quilombola? Pensamos que sim. Argumentamos no sentido de terem sido criados conteúdos e significados culturais nas senzalas e nos quilombos brasileiros. Melhor seria falar em recriações e reinvenções. Para além de algumas poucas e dispersas evidências - e a necessidade permanente de se remover o pó da documentação disponível depositada nos arquivos locais - baseamo-nos num amplo debate teórico e metodológico sobre as especificidades de uma cultura afro-americana. Os principais passos a serem seguidos são as análises pioneiras (o debate vem de longa data, porém) de Mintz e Price. (MINTZ\&PRICE, 1976; AGORSAH, 1994; BLASSINGAME\&BERRY, 1982; MULLIN, 1992; PALMIÉ, 1995; STUCKEY, 1987; THOMPSON, 1983; THORNTON, 1992)

Argumentamos também a favor da gestação de culturas escravas em várias partes do Brasil. Significados culturais de origem africana eram reinventados pelos escravos no Brasil, não só para a primeira geração de africanos, mas também aquela de cativos crioulos (SLENES, 1994; SLENES, 1992; SLENES, 1988; SLENES, 1995). Nesse sentido, pensamos a cultura quilombola, não numa perspectiva essencialista de "africanismos" -- como se os quilombos fossem necessariamente e/ou exclusivamente lugares ou guardiães da "cultura africana". Esses pressupostos marcaram os estudos sobre os quilombos brasileiros desde a década de 30, numa proposta de análise culturalista.

Consideramos aqui a cultura quilombola (ou culturas quilombolas, para marcar sua complexidade e diversidade) como uma extensão da cultura escrava. As senzalas podiam ser fontes constantes de backgrounds culturais para os quilombolas, como estes para as mesmas. É claro que, em algumas situações, os impactos demográficos do tráfico negreiro, a crioulização das populações dos mocambos e das senzalas e o isolamento forçado de alguns grupos quilombolas podem ter provocado interações culturais diferentes. $\mathrm{O}$ fato é que os quilombos - de uma maneira geral - não estavam completamente afastados das senzalas e de outros setores escravos, livres e negros. Desse modo, aquilo que chamamos de cultura escrava e/ou quilombola podia alcançar os não-escravos, aqueles que estivessem fora dos quilombos (ou que com eles mantivessem apenas contatos esporádicos), libertos, índios, brancos e outros setores da sociedade.

\footnotetext{
${ }^{36}$ Ibid., pp. 55. Em jornais do Maranhão, ver noticiários publicados nos dias 9 e 25/01 e 22 e 23/03 de 1877 no Diário do Maranhão.
} 
No caso do Turiaçu-Gurupi, é possível considerar a gestação de uma cultura camponesa fortemente marcada pela presença de negros e índios. As matrizes culturais africanas reinventadas estavam ali presentes. Havia o círculo nos quilombos. Os transes e as cabaças de "ervas podres" podiam, por exemplo, estar juntando experiências indígenas e africanas diversas. Os cachorros - dezenas foram encontrados nos quilombos -- tinham grande importância para alguns grupos indígenas, como os Urubus (Kaapor). Podia haver trocas. De igual modo, a cultura do quilombo descrita por ocasião dessas expedições podia ser algo familiar e ao mesmo tempo estranho. Freire Jr. foi rápido e classificou tudo no Limoeiro de "casa de pajé". Já Ferreira Caldas, numa noite no São Sebastião, diria: "como estivesse bonito o luar mandei lembrar-lhes a dança do tambor, ao que prontamente anuíram, e levaram a brincar até duas horas da madrugada". As "cruzes" em algumas "casa[s] de oração" e "casas de santo" nesses quilombos devem ter assustado alguns. As perspectivas destas expedições tinham um quê de "civilizatórias". Ao chegar aos mocambos encontrariam um dos maiores símbolos da "civilização".

Há outras questões para análises. Num primeiro momento poderíamos pensar essas "cruzes", "capelas" e "casas de santo" como simplesmente influências religiosas de um catolicismo das senzalas. Porém havia já na África colonial - especialmente nas áreas centrais do continente - dos séculos XV a XVIII, o impacto do cristianismo através de missionários europeus. Mais do que isso, a simbologia da cruz podia já ter outros significados para alguns grupos étnicos africanos.

O que importa aqui - destacando os quilombos maranhenses - é pensar tal evidência e outras sobre a cultura dos africanos e seus descendentes nas Américas como reinvenções e reapropriações históricas permanentes.

\section{Bibliografia}

AGORSAH, E. Kofi. "Background to Maroon Heritage". Maroon Heritage. Archaelogical Ethnografic and Historical Perspectives. (Org. E. Kofi Agorsah). University of the West Indies, 1994.

ARAÚJO, Mundinha. A Invasão do quilombo Limoeiro. São Luís, SIOGE, 1998.

AZEVEDO, Célia Maria Marinho de. Onda Negra, Medo Branco. O Negro no Imaginário das Elites - século XIX, São Paulo, Paz e Terra, 1987.

BEZERRA NETO, José Maia. Fugindo, sempre fugindo. Escravidão, fugas escravas e fugitivos no Grão-Pará (1840-1888). Dissertação de Mestrado, Unicamp, 2001. 
BLASSINGAME, John W. \& BERRY, Mary Francis. "Africa, Slavery, and the Shaping of Black Culture". Long Memory. The Black Experience in America. Nova Iorque, Oxford University Press, 1982.

BRANDÃO JUNIOR, Francisco Antônio. A Escravatura no Brasil precedida d'um Artigo Sobre Agricultura e Colonização no Maranhão. Bruxelas, 1865.

CARVAlHO, José Murilo de. Teatro de Sombras. A Política Imperial. Rio de Janeiro, IUPERJ, 1988.

CONRAD, Robert. Os últimos anos da escravatura no Brasil. Rio de Janeiro, Civilização Brasileira, 1976.

FUNES, Eurípedes. "Nasci nas matas, nunca tive senhor". História e Memória dos mocambos do Baixo Amazonas. Tese de Doutorado, São Paulo, FFLCH/USP, 1995.

FUNES, Eurípedes. "Nasci nas matas, nunca tive senhor". História e Memória dos mocambos do Baixo Amazonas", In: REIS, João \& GOMES, Flávio dos Santos. Liberdade por um Fio: Histórias dos quilombos no Brasil. São Paulo: Companhia das Letras, 1996, pp. 467-497.

GOMES, Flavio dos Santos. "Uma lança em África": notas sobre fontes e narrativas numa repressão anti-mocambo no Maranhão Oitocentista", in: GOMES, Flávio dos Santos. Experiências atlânticas: Ensaios e pesquisas sobre a escravidão e o pós-emancipação no Brasil. Passo Fundo-RS: UPF Editora -- Universidade de Passo Fundo-RS, 2003.

GOMES, Flávio dos Santos. "Roceiros, mocambeiros e as fronteiras da emancipação no Maranhão" in: Olivia Cunha e Flávio Gomes (Organizadores). Quase-Cidadão: Histórias e antropologias no Brasil da pós-emancipação no Brasil. Rio de Janeiro: FGV, 2007,. pp. 147-170.

GOMES, Flávio dos Santos. A Hydra e os pantânos. Mocambos, quilombos e comunidades de fugitivos no Brasil escravista (séc. XVII-XIX). São Paulo: Polis/UNESP, 2005.

GOMES, Flávio dos Santos. "Do outro lado da floresta: Terra e memória dos mocambos do Gurupi” Ciência Hoje, Rio de Janeiro, volume 30, número 179, pp. 26-31, 2002.

GOMES, Flávio dos Santos. Histórias de Quilombolas. Mocambos e Comunidades de Senzalas. Rio de Janeiro, Arquivo Nacional, 1995.

MINTZ, Sidney W. \& PRICE, Richard. An Anthropological Aproach to the Afro-American Past; A Caribbean Perspective. Philadelfia, ISHI, 1976.

MULLIN, Michael. Africa in America. Slave Acculturation and Resistance in the America South and the British Caribbean, 1736-1831., University of Illinois Press, 1992.

PALMIÉ, Stephan. (org.). Slave Cultures and the Cultures of Slavery. Knoxville, The University of Tennesse Press, 1995.

SACRAMENTO BLAKE, Augusto Victorino Alves. Diccionário Bio-Bibliográphico. Rio de Janeiro: Imprensa Nacional, 1937. 
SLENES, Robert W. Na senzala, uma flor: as esperanças e as recordações na formação da família escrava, Texto inédito, julho 1994.

SLENES, Robert W. "'Malungu, ngoma vem !': África coberta e descoberta no Brasil". Revista USP, São Paulo, número 12, 1991/1992.

SLENES, Robert W. "Lares Negros, olhares brancos: Histórias da família escrava no século XIX". Revista Brasileira de História, São Paulo. ANPUH/Marco Zero, volume 8, número 16, mar./ago. 1988, pp. 189-203.

SLENES, Robert W. "Central-African Water Spirits in Rio de Janeiro: Slave identify and Rebellion in Early-Nineteenth Century Brazil". Texto inédito, abril 1995.

SLENES, Robert W. "As provações de um Abraão africano: a nascente nação brasileira na viagem alegórica de Johann Moritz Rugendas". Revista de História da Arte e Arqueologia, número 2, IFCH/UNICAMP, 1995-96, pp. 271-536.

STUCKEY, Sterling. Slave Culture: Nationalist Theory and The Foundations of black America, Nova Iorque, 1987.

THOMPSON, Robert Farris. Flash of The Spirit. Nova Iorque, 1983.

THORNTON, John K. Africa and Africans in the Making of the Atlantic World, 1400-1680, Cambridge University Press, 1992. 